\title{
ESSENTIAL OIL COMPOSITION AND IN VITRO ANTIBACTERIAL ACTIVITY OF CHENOPODIUM ALBUM SUBSP. STRIATUM
}

\author{
Negin Khomarlou, ${ }^{1}$ Parviz Aberoomand-Azar, ${ }^{1 *}$ \\ Ardalan Pasdaran Lashgari, ${ }^{2}$ Hamid Tebyanian, ${ }^{3,4}$ Ali Hakakian, ${ }^{5 *}$ \\ ReZa RanjBar $^{6}$ and Seyed Abdolmajid Ayatollahi ${ }^{7}$
}

${ }^{1}$ Department of Chemistry, Science and Research Branch, Islamic Azad University, Tehran, Iran ${ }^{2}$ Medicinal Plants Processing Research Center, Shiraz University of Medicinal Sciences, Shiraz, Iran ${ }^{3}$ Research Center for Prevention of Oral and Dental Disease, Baqiyatallah University of Medical Sciences, Tehran, Iran

${ }^{4}$ Nanobiotechnology Research Center, Baqiyatallah University of Medical Sciences, Tehran, Iran ${ }^{5}$ Faculty Member of Production and Research Complex, Pasteur Institute of Iran, Tehran, Iran ${ }^{6}$ Molecular Biology Research Center, Baqiyatallah University of Medical Sciences, Tehran, Iran ${ }^{7}$ Phytochemistry Research Center, Shahid Beheshti University of Medicinal Sciences, Tehran, Iran

(Received: November 9, 2017; accepted: January 29, 2018)

\begin{abstract}
The objective of this study was to identify the bioactive compounds of essential oil and evaluate the antibacterial activity of the essential oil extracted from Chenopodium album subsp. striatum against multidrug-resistant bacterial strains (MDR) which were isolated from clinical specimens by conventional methods. Furthermore, eight different Gram-negative and Gram-positive multidrug-resistant bacterial strains were used to investigate the antibacterial potential of the essential oil. The antibacterial activity was tested using MIC and MBC microdilution method, well and disc diffusion in different concentration. The hydro-distillation of aerial parts powder yield was $0.466 \%(\mathrm{v} / \mathrm{w})$. Essential oil showed bactericidal activity against both MDR Gram-negative and Gram-positive bacterial strains. MIC and MBC results were ranged from 0.31 to 2.5 and 0.62 to $5.0 \mathrm{mg} / \mathrm{mL}$. The inhibition zones in well-diffusion method were ranged from $7 \pm 0.6 \mathrm{~mm}$ to $15 \pm 1.0 \mathrm{~mm}$. Disc diffusion method was ranged from $7 \pm 0.0 \mathrm{~mm}$ to $16 \pm 0.6$ $\mathrm{mm}$ depending on the type of bacteria strain and essential oil concentration. Essential oil of Ch. album had the greatest potential to be considered as an antibacterial agent against MDR bacteria strain. This potential was due to different biological and bioactive compounds like phytol, linalool, $\alpha$-terpineol and linolenic acid in the plant.
\end{abstract}

Keywords: GC analysis - multidrug-resistant bacterial strains - Chenopodium album subsp. striatum

\section{INTRODUCTION}

In recent years, there is a significant interest in medicinal plants and their metabolites because most of them have several advantages such as efficacy, cultural acceptability, and better compatibility with human body, as well as lesser side effects. One-quarter of all prescribed pharmaceuticals in developed countries contain compounds derived directly or indirectly from plants $[15,26]$. Many compounds of plant origin have been used for centuries as remedies for human diseases. Nowadays, there is a broad inter-

*Corresponding authors; e-mail addresses: parvizaberoomand@gmail.com; ali.hakakian@gmail.com 
est in plant remedies. Green medicine is reported as efficacy and reliable practice because of secondary metabolites which also have therapeutic properties, and the formulation of plants for standardization and the regulation of phytomedicinal products are the most alternative way recently [1, 25, 42]. On the other hand, infections due to pathogenic microorganism especially bacterial strain can cause serious clinical problems $[32,35]$. In recent years, antibiotic resistance has become a serious and widespread problem in developing countries because of inappropriate usage, abusive and over prescription of antibiotics causing mortality each year [29, 39]. Global emergence of resistant bacteria is the result of the ineffectiveness of current antibiotics and drugs causing treatment failure [10]. Hence, there is a growing interest in alternative therapy and therapeutic use of natural products especially medicinal plants [1]. Essential oil of plants may inhibit the growth of broad spectrum of pathogenic microorganisms drawing the attention for their biological and bioactive compounds with antimicrobial activity [3]. The term of "essential oil" has been used in the $16^{\text {th }}$ century for the first time by Paracelsus von Hohenhem. Essential oils are a mixture of natural, volatile and complex constituents which are produced by plant organs especially in aromatic plants considered as secondary metabolites. They were characterized by their strong fragrance, solubility in organic and lipid solvents, colorless, etc. As Bassole stated among the 100,000 known secondary metabolites, essential oils account for over 3000 , of which about 300 have commercial purposes and are used by the food, cosmetic and pharmaceutical industries [4, 16, 17, 34]. Essential oils contain two main constituents which responsible for diverse chemical, biochemical and pharmaceutical activity: terpenes (monoterpenes and sesquiterpenes) and terpenoids (isoprenoids), and another group of aliphatic and aromatic compounds (e.g. aldehydes, phenols).

A wide range of plant including Chenopodium album subsp. striatum is discovered to present therapeutic effects. Chenopodium album subsp. striatum belonging to the family Chenopodiaceae (goosefoot family) which is one of the largest families of the flowering and annual plants including 104 genus and more than 1400 species [23, 33]. They widely spread worldwide from the moderate and subtropical zone to arid and saline regions. Iran with the surface area of $1,648,000 \mathrm{~km}^{2}$ has a large area of saline and arid rangelands. The harsh and halophyte ecosystems provide a suitable condition for growing and cultivation of many plant species such as Ch. album subsp. striatum [11]. Chenopodium album is known to be a rich source of flavonoid, glucosides, terpenoids, and phenolic acid. The leaves are rich in carotenoids and the seeds in proteins and fats $[24,30]$. Many Chenopodium species were reported to have numerous medicinal properties such as antipruritic, antibacterial, antifungal, and anticancer effect $[6,13,19]$.

Ch. album subsp. striatum has been locally used for its traditional and medicinal properties, however, its efficacies against MDR bacteria have not been studied. Hence, in this study we were intended for retrieving the attention of scientific community on the antibacterial activity of the essential oil and provide to develop new drug from natural products. Their constituents can be presumably considered in the future for more clinical investigations and as adjuvants to current medications. 
The present study was designed to determine the role of the essential oil of Ch. album subsp. striatum for potential antibacterial activity according to the standard protocols by agar-based methods and MIC, MBC tests against some selected MDR Gram-positive and Gram-negative bacteria like Staphylococcus aureus, Escherichia coli, Shigella flexneri, Sh. sonnei, Sh. dysenteriae, Salmonella typhimurium, $S$. enteritidis, and $S$. infantis. The aim of this study was to screen the in vitro antimicrobial activity of the plant as potential sources of natural antimicrobial agents.

\section{MATERIALS AND METHODS}

\section{Plant material by tissue culture}

Ch. album subsp. striatum was obtained from tissue culture. The basal medium was made up with Murashige and Skoog Salt, vitamins supplements, 3\% sucrose without any hormones and also solidified with $0.7 \%(\mathrm{w} / \mathrm{v})$ plant agar. The medium was adjusted to $\mathrm{pH} 5.8$ before adding plant agar, and then it was sterilized by autoclaving at $121{ }^{\circ} \mathrm{C}$ for $20 \mathrm{~min}$ [21]. The primary plant sample was identified by Plant Physiology Laboratory and voucher specimens were confirmed and deposited in the Herbarium (No. 2565) at the Department of Pharmacy, Faculty of Pharmacy, Shahid Beheshti University of Medicinal Sciences. Aerial parts of the plant were washed thoroughly 2-3 times with running tap water and then once with distilled water, then they were dried in shady place for a period of 3-4 days at room temperature, and finally they were subsequently ground into a fine powder using grinding mill and kept in air tight amber glass vials.

\section{Essential oil procedure}

The shade-dried plant material $(500 \mathrm{~g})$ were subjected to hydrodistillation for $4 \mathrm{~h}$ using Clevenger-type apparatus. Afterwards, the essential oil was dried over anhydrous sodium sulfate. The hydrodistilled essential oil yield was $0.466 \%(\mathrm{v} / \mathrm{w})$. Finally, it was preserved at $4{ }^{\circ} \mathrm{C}$ in a sealed vial for further analysis, i.e. GC-MS and antimicrobial activity.

\section{GC-MS analysis}

GC-MS analysis of essential oil obtained from aerial parts was carried out using an Agilent 7890B/5975C GC-MSD on HP-5MS capillary column $(30 \mathrm{~m} \times 0.25 \mu \mathrm{m}$, i.d. $0.25 \mathrm{~mm}$ ) and a $5975 \mathrm{C}$ mass selective detector. The $70 \mathrm{eV}$ ionization energy was used for electron ionization. Diluted sample $(1 \mu \mathrm{L}, 1 / 10 \mathrm{v} / \mathrm{v}$ in methanol) was manually injected with a split ratio of 1:10. Inert helium gas was used as carrier gas at constant 
flow rate of $1 \mathrm{~mL} / \mathrm{min}$. The first oven temperature was held at $50{ }^{\circ} \mathrm{C}$ for $2 \mathrm{~min}$, then it gradually increased to $290{ }^{\circ} \mathrm{C}$ at $5{ }^{\circ} \mathrm{C} / \mathrm{min}$ rate and held at $290{ }^{\circ} \mathrm{C}$ for $10 \mathrm{~min}$. Injector and mass transfer line temperatures were set at $220^{\circ} \mathrm{C}$ and $300{ }^{\circ} \mathrm{C}$, respectively. The relative percentage of the essential oil constituents was expressed as the percentage by peak area normalization. Identification of compound was based on the comparison of the retention time and mass spectra with NIST GC-MS library and also those obtained from literature data.

\section{Bacterial preparation}

The used Gram-positive and Gram-negative species were Staphylococcus aureus, Escherichia coli, Shigella flexneri, Sh. sonnei, Sh. dysenteriae, Salmonella typhimurium, S. enteritidis, and S. infantis. Bacteria species were taken from isolated specimens which exhibited resistance to some antibiotics in hospitalized patients. They were taken based on ethical clearance approval from the ethical committee in hospital. They were cultured over night at $37^{\circ} \mathrm{C}$ on nutrient broth for the preparation of cell suspensions. The bacteria cell suspensions were homogenized and adjusted to 0.5 McFarland standards. Commercial antibiotic discs of Ampicillin $(10 \mu \mathrm{g} / \mathrm{disc})$, Amikacin $(30 \mu \mathrm{g} / \mathrm{disc})$, Amoxicillin-clavulanic acid (30 $\mu \mathrm{g} / \mathrm{disc})$, Azithromycin (30 $\mu \mathrm{g} / \mathrm{disc})$, Cefazoline $(30 \mu \mathrm{g} / \mathrm{disc})$, Cefixime $(5 \mu \mathrm{g} / \mathrm{disc})$, Cefotaxime $(30 \mu \mathrm{g} / \mathrm{disc})$, Cefoxitin $(30 \mu \mathrm{g} / \mathrm{disc})$, Cefpiramide $(30 \mu \mathrm{g} / \mathrm{disc})$, Ceftazidime $(30 \mu \mathrm{g} / \mathrm{disc})$, Ceftizoxime $(30 \mu \mathrm{g} / \mathrm{disc})$, Ceftriaxone $(30 \mu \mathrm{g} / \mathrm{disc})$, Cephalothin $(30 \mu \mathrm{g} / \mathrm{disc})$, Chloramphenicol (30 $\mu \mathrm{g} / \mathrm{disc})$, Ciprofloxacin $(5 \mu \mathrm{g} / \mathrm{disc})$, Clindamycin $(2 \mu \mathrm{g} / \mathrm{disc})$, Doxycycline $(30 \mu \mathrm{g} / \mathrm{disc})$, Erythromycin $(15 \mu \mathrm{g} / \mathrm{disc})$ Gentamycin $(10 \mu \mathrm{g} / \mathrm{disc})$, Imipenem (10 $\mu \mathrm{g} / \mathrm{disc})$, Kanamycin (30 $\mu \mathrm{g} / \mathrm{disc})$, Nalidixic acid $(30 \mu \mathrm{g} / \mathrm{disc})$, Norfloxacin $(10 \mu \mathrm{g} / \mathrm{disc})$, Piperacillin $(100 \mu \mathrm{g} / \mathrm{disc})$, Rifampin $(5 \mu \mathrm{g} / \mathrm{disc})$, Streptomycin $(10 \mu \mathrm{g} / \mathrm{disc})$, Tetracyclin $(30 \mu \mathrm{g} / \mathrm{disc})$, Ticarcillin $(75 \mu \mathrm{g} / \mathrm{disc})$, Tobramycin $(10 \mu \mathrm{g} / \mathrm{disc})$ and Trimethoprim-sulfamethoxazole $(25 \mu \mathrm{g} / \mathrm{disc})$ were used for assessment of their activity and sensitivity against the tested bacteria strains. Each antimicrobial assay was performed in triplicate for more accuracy.

\section{Determination of antibacterial activity of essential oil}

The hydrodistilled essential oil was first dissolved up to $5 \% \mathrm{v} / \mathrm{v}$ of total essential oil in DMSO (dimethyl sulfoxide) to the final concentration of $10 \mathrm{mg} / \mathrm{mL}$ for MIC (minimum inhibitory concentration) and $\mathrm{MBC}$ (minimum bactericidal concentration) assay and then they were sterilized through filtration system using $0.45 \mu \mathrm{m}$ membrane filters. The antibacterial activity was determined by agar well and disc diffusion methods also MIC and MBC assay [13]. The protocol of the study was based on CLSI guidelines. 


\section{Agar well-diffusion method}

The antimicrobial activity of the essential oil was screened by agar well diffusion method as described by Pérez et al. [28]. Bacterial strains were grown on nutrient agar at $37^{\circ} \mathrm{C}$ for $18 \mathrm{~h}$ and then they were suspended in LB broth adjusted to a turbidity of 0.5 MacFarland standards $\left[\sim 10^{8}\right.$ Colony Forming Units $\left.(\mathrm{CFU}) / \mathrm{mL}\right]$. Fifty $\mu \mathrm{L}$ inoculum suspension was swabbed uniformly to solidified $25 \mathrm{~mL}$ Mueller-Hinton Agar (MHA) for bacteria. Afterwards, the inoculum was allowed to dry for $5 \mathrm{~min}$. Wells with $6 \mathrm{~mm}$ of diameter were punched in the agar and finally filled with $50 \mu \mathrm{L}$ of $35,40,45,50,55$ and $60 \mathrm{mg} / \mathrm{mL}$ essential oil solution. The plate was allowed to stand on the bench for $1 \mathrm{~h}$ for proper diffusion and then they were incubated at $37^{\circ} \mathrm{C}$ for $24 \mathrm{~h}$. The antibacterial activity was evaluated by measuring the inhibition zone diameter observed. The experiments were performed in triplicate.

\section{Agar disc diffusion}

The antibacterial activity was also tested by disc diffusion method. The method for growing of bacterial strains as same as the one which was described in well diffusion method but instead of creating wells, we used blank discs with $6 \mathrm{~mm}$ of diameter. Each disc was soaked with about $10 \mu \mathrm{L}$ of $35,40,45,50,55$ and $60 \mathrm{mg} / \mathrm{mL}$ of essential oil solution. Six discs were placed on each Petri dish. The plates were incubated at $37^{\circ} \mathrm{C}$ for $24 \mathrm{~h}$ and finally, the inhibition zones were measured in $\mathrm{mm}$. The test was carried out in triplicate.

\section{Minimum inhibitory concentration}

In order to determine MIC, serial twofold dilutions plant essential oil was made in a concentration from $10 \mathrm{mg} / \mathrm{mL}$ to $0.005 \mathrm{mg} / \mathrm{mL}$ in sterile 96-well plates as described by Clinical and Laboratory Standards Institute (CLSI). These dilutions were added to tubes containing $100 \mu \mathrm{L}$ Muller Hinton broth and $5 \mu \mathrm{L}$ of bacterial suspension. Microplates were incubated at $37^{\circ} \mathrm{C}$ for $24 \mathrm{~h}$. The lowest concentration of the essential oil in broth medium inhibited the growth of the tested microorganisms was considered as MIC. DMSO was used as a control and Mueller-Hinton broth as a negative control $[18,40]$.

\section{Minimum bactericidal concentration}

To determine the MBC, about $10 \mu \mathrm{L}$ of broth from tubes, which did not exhibit any visible growth in the MIC assay, were cultured on freshly prepared sterile MullerHinton agar, and then they were incubated at $37^{\circ} \mathrm{C}$ for $18-24 \mathrm{~h}$. After incubation, the highest dilution (least concentration) inhibited colony formation on solid medium was considered as $\mathrm{MBC}[27,41]$. 


\section{Statistical analysis}

Measured data were expressed as means $\pm \operatorname{SEM}(n=3)$.

\section{RESULTS}

\section{Chemical composition of essential oil}

GC-MS analysis of the essential oil of Ch. album subsp. striatum resulted 36 different organic and bioactive compounds which represented $97.09 \%$ of the total oil. The result of the GC-MS analysis is listed in Table 1 based on their elution orders. The essential oil contained complex mixture mainly consisted of higher hydrocarbons (71.99\%), oxygenated $(6.58 \%)$ and bicyclic mono-, di- and sesquiterpenoids $(6.56 \%)$, and also fatty acids $(8.51 \%)$. Phytol was the most oxygenated diterpene in the oil (3.07\%), while linalool (1.94\%) and $\alpha$-terpineol (1.57\%) were the most abundant oxygenated monoterpene. Linolenic acid $(2.53 \%)$ as fatty acid was also found in appreciable proportion in the sample.

\section{Antibacterial activity of essential oil}

The antibacterial activity against MDR bacteria obtained by agar well, disc diffusion and microdilution assay (MIC and MBC) are shown in Tables 2, 3 and 4. The results of the present research revealed considerable antibacterial activity against MDR microorganism. The inhibition zones were in the range of $7.0 \pm 0.6 \mathrm{~mm}$ to $15.0 \pm 1.0$ $\mathrm{mm}$ in well diffusion method and $7.0 \pm 0.0 \mathrm{~mm}$ to $16.0 \pm 0.6 \mathrm{~mm}$ in disc diffusion method (Tables 2, 3).

The MIC value ranged from $0.31 \mathrm{mg} / \mathrm{mL}$ to $2.5 \mathrm{mg} / \mathrm{mL}$ and the $\mathrm{MBC}$ value of the essential oil ranged from $0.62 \mathrm{mg} / \mathrm{mL}$ to $5 \mathrm{mg} / \mathrm{mL}$ (Table 4). The essential oil showed greater inhibitory effect on the growth of S. typhimurium and Sh. dysenteriae, while it had no antimicrobial effect against $S$. enteritidis by microdilution methods. It is important to mention that discrimination of the endpoint bacteria growth in MIC and MBC methods was based on the determination of OD (optical density measured by Elisa reader), so that OD of the wells has to be near the OD of blank (without bacteria). On the other hand, the solvent (up to $5 \%$ DMSO) did not inhibit the growth of the tested bacteria strains.

The results of panel test of Staphylococcus aureus, Escherichia coli, Shigella flexneri, Sh. sonnei, Sh. dysenteriae, Salmonella typhimurium, S. enteritidis and S. infantis are summarized in Table 5, in points of resistance to antibiotics for in vitro antibacterial screening. 
Table 1

Chemical composition of Ch. album subsp. striatum essential oil

\begin{tabular}{|c|c|c|c|c|}
\hline No & Chemical compounds & Formula & \begin{tabular}{c|} 
Kovats \\
Retention Index
\end{tabular} & $\begin{array}{c}\text { Peak area } \\
(\%)\end{array}$ \\
\hline 1 & Cyclohexane, methyl- & $\mathrm{C}_{7} \mathrm{H}_{14}$ & 755 & 9.55 \\
\hline 2 & Heptane, 3-methyl- & $\mathrm{C}_{8} \mathrm{H}_{18}$ & 775 & 8.61 \\
\hline 3 & Octane & $\mathrm{C}_{8} \mathrm{H}_{18}$ & 800 & 8.32 \\
\hline 4 & $\alpha$-Pinene & $\mathrm{C}_{10} \mathrm{H}_{16}$ & 933 & 1.21 \\
\hline 5 & $\beta$-Pinene & $\mathrm{C}_{10} \mathrm{H}_{16}$ & 976 & 0.87 \\
\hline 6 & Decane & $\mathrm{C}_{10} \mathrm{H}_{22}$ & 999 & 8.11 \\
\hline 7 & Linalool & $\mathrm{C}_{10} \mathrm{H}_{18} \mathrm{O}$ & 1098 & 1.94 \\
\hline 8 & $\alpha$-Terpineol & $\mathrm{C}_{10} \mathrm{H}_{18} \mathrm{O}$ & 1198 & 1.57 \\
\hline 9 & Ascaridole & $\mathrm{C}_{10} \mathrm{H}_{16} \mathrm{O}_{2}$ & 1237 & 1.44 \\
\hline 10 & $\begin{array}{l}2(1 \mathrm{H})-\text { Naphthalenone, octahydro-8a-methyl-, } \\
\text { trans- }\end{array}$ & $\mathrm{C}_{11} \mathrm{H}_{18} \mathrm{O}_{2}$ & 1279 & 2.66 \\
\hline 11 & Carvacrol & $\mathrm{C}_{10} \mathrm{H}_{14} \mathrm{O}$ & 1298 & 0.82 \\
\hline 12 & Tetradecane & $\mathrm{C}_{14} \mathrm{H}_{30}$ & 1399 & 7.01 \\
\hline 13 & $\beta$-Caryophyllene & $\mathrm{C}_{15} \mathrm{H}_{24}$ & 1467 & 1.44 \\
\hline 14 & $\beta$-Ionone & $\mathrm{C}_{13} \mathrm{H}_{20} \mathrm{O}$ & 1494 & 0.59 \\
\hline 15 & Isoaromadendrene epoxide & $\mathrm{C}_{15} \mathrm{H}_{24} \mathrm{O}$ & 1590 & 1.32 \\
\hline 16 & Geranyl isovalerate & $\mathrm{C}_{15} \mathrm{H}_{26} \mathrm{O}_{2}$ & 1599 & 1.41 \\
\hline 17 & $\begin{array}{l}\text { 4-(6,6-Dimethyl-1-cyclohexen-1-yl)-3-buten- } \\
\text { 2-one }\end{array}$ & $\mathrm{C}_{12} \mathrm{H}_{18} \mathrm{O}$ & 1609 & 0.91 \\
\hline 18 & 4-Acoren-3-one & $\mathrm{C}_{15} \mathrm{H}_{24} \mathrm{O}$ & 1649 & 0.23 \\
\hline 19 & Tetradecane, 2,6,10-trimethyl- & $\mathrm{C}_{17} \mathrm{H}_{36}$ & 1700 & 8.49 \\
\hline 20 & Octadecane & $\mathrm{C}_{18} \mathrm{H}_{38}$ & 1800 & 4.11 \\
\hline 21 & Phytane & $\mathrm{C}_{20} \mathrm{H}_{42}$ & 1812 & 0.78 \\
\hline 22 & Methyl palmitate & $\mathrm{C}_{17} \mathrm{H}_{34} \mathrm{O}_{2}$ & 1908 & 0.61 \\
\hline 23 & Dibutyl phthalate & $\mathrm{C}_{16} \mathrm{H}_{22} \mathrm{O}_{4}$ & 1922 & 0.23 \\
\hline 24 & 2-Piperidinone, N-[4-bromo-n-butyl]- & $\mathrm{C}_{9} \mathrm{H}_{16} \mathrm{BrNO}$ & 1974 & 1.32 \\
\hline 25 & 10-Octadecenal & $\mathrm{C}_{18} \mathrm{H}_{34} \mathrm{O}$ & 1977 & 3.36 \\
\hline 26 & Eicosane & $\mathrm{C}_{20} \mathrm{H}_{42}$ & 2000 & 1.78 \\
\hline 27 & 12-Methyl-E,E-2,13-octadecadien-1-ol & $\mathrm{C}_{19} \mathrm{H}_{36} \mathrm{O}$ & 2052 & 2.06 \\
\hline 28 & Oleyl alcohol & $\mathrm{C}_{18} \mathrm{H}_{36} \mathrm{O}$ & 2060 & 1.493 \\
\hline 29 & Methyl oleate & $\mathrm{C}_{19} \mathrm{H}_{40}$ & 2085 & 0.71 \\
\hline 30 & Phytol & $\mathrm{C}_{20} \mathrm{H}_{40} \mathrm{O}$ & 2105 & 3.07 \\
\hline 31 & Linolenic acid & $\mathrm{C}_{18} \mathrm{H}_{30} \mathrm{O}_{2}$ & 2122 & 2.53 \\
\hline 32 & Glyceryl linolenate & $\mathrm{C}_{21} \mathrm{H}_{36} \mathrm{O}_{4}$ & 2161 & 0.93 \\
\hline 33 & Tetrahydro-2H-Pyran, 2-(7-heptadecynyloxy) & $\mathrm{C}_{22} \mathrm{H}_{40} \mathrm{O}_{2}$ & 2566 & 0.63 \\
\hline 34 & Meadowlactone & $\mathrm{C}_{20} \mathrm{H}_{38} \mathrm{O}_{2}$ & 2573 & 0.83 \\
\hline 35 & Heptacosane & $\mathrm{C}_{27} \mathrm{H}_{56}$ & 2700 & 4.84 \\
\hline 36 & Disogenin & $\mathrm{C}_{27} \mathrm{H}_{42} \mathrm{O}_{3}$ & 3220 & 1.31 \\
\hline Total & & & & 97.09 \\
\hline
\end{tabular}


Table 2

Antibacterial effect of Ch. album subsp. striatum essential oil by agar well diffusion in six different concentration $(35,40,45,50,55$ and $60 \mathrm{mg} / \mathrm{mL}$, respectively)

\begin{tabular}{|c|c|c|c|c|c|c|}
\hline \multirow{3}{*}{ Studied bacteria } & \multicolumn{6}{|c|}{ Inhibition zone (mm) } \\
\hline & \multicolumn{6}{|c|}{ Concentrations (mg/mL) } \\
\hline & 60 & 55 & 50 & 45 & 40 & 35 \\
\hline Escherichia coli & $12 \pm 0.6$ & $12 \pm 0.0$ & $10 \pm 0.0$ & $8 \pm 1.0$ & - & - \\
\hline Shigella flexneri & $10 \pm 0.0$ & $8 \pm 0.6$ & $7 \pm 0.6$ & - & - & - \\
\hline Shigella sonnei & $12 \pm 0.6$ & $9 \pm 0.6$ & - & - & - & - \\
\hline Shigella dysenteriae & $13 \pm 1.0$ & $10 \pm 0.0$ & $7 \pm 0.6$ & - & - & - \\
\hline Salmonella infantis & $11 \pm 0.6$ & $8 \pm 0.6$ & $8 \pm 0.0$ & - & - & - \\
\hline Salmonella enteritidis & $7 \pm 0.6$ & - & - & - & - & - \\
\hline Salmonella typhimurium & $15 \pm 1.0$ & $11 \pm 0.6$ & $11 \pm 1.0$ & $9 \pm 0.0$ & - & - \\
\hline Staphylococcus aureus & $12 \pm 0.6$ & $10 \pm 0.0$ & $8 \pm 0.0$ & $7 \pm 1.0$ & - & - \\
\hline
\end{tabular}

Table 3

Antibacterial effect of Ch. album subsp. striatum essential oil by agar disc diffusion in six different concentration $(35,40,45,50,55$ and $60 \mathrm{mg} / \mathrm{mL}$, respectively)

\begin{tabular}{|l|c|c|c|c|c|c|}
\hline \multirow{2}{*}{} & \multicolumn{7}{|c|}{ Inhibition zone (mm) } \\
\cline { 2 - 7 } & \multicolumn{7}{|c|}{ Concentrations (mg/mL) } \\
\cline { 2 - 7 } & 60 & 55 & 50 & 45 & 40 & 35 \\
\hline Escherichia coli & $13 \pm 0.6$ & $13 \pm 1.0$ & $11 \pm 0.6$ & $10 \pm 0.0$ & - & - \\
\hline Shigella flexneri & $12 \pm 0.6$ & $11 \pm 1.0$ & $9 \pm 1.0$ & $9 \pm 0.6$ & $8 \pm 0.6$ & - \\
\hline Shigella sonnei & $14 \pm 0.0$ & $12 \pm 0.6$ & $11 \pm 0.6$ & $10 \pm 0.6$ & $8 \pm 0.0$ & - \\
\hline Shigella dysenteriae & $14 \pm 1.0$ & $11 \pm 0.0$ & $9 . \pm 0.6$ & $8 \pm 0.0$ & - & - \\
\hline Salmonella infantis & $12 \pm 1.0$ & $11 \pm 1.0$ & $9 \pm 0.6$ & $8 \pm 0.0$ & $8 \pm 0.0$ & - \\
\hline Salmonella enteritidis & $9 \pm 0.0$ & $8 \pm 0.6$ & $8 \pm 0.6$ & - & - & - \\
\hline Salmonella typhimurium & $16 \pm 0.6$ & $14 \pm 0.0$ & $12 \pm 1.0$ & $10 \pm 0.6$ & $8 \pm 0.6$ & - \\
\hline Staphylococcus aureus & $14 \pm 1.0$ & $13 \pm 1.0$ & $11 \pm 0.6$ & $9 \pm 0.6$ & $7 \pm 0.6$ & $7 \pm 0.0$ \\
\hline
\end{tabular}

Table 4

MIC and MBC of Ch. album subsp. striatum essential oil against the tested bacteria

\begin{tabular}{|l|c|c|}
\hline \multicolumn{1}{|c|}{ Studied bacteria } & MIC & MBC \\
\hline Escherichia coli & 1.25 & 2.5 \\
\hline Shigella flexneri & 2.5 & 5 \\
\hline Shigella sonnei & 1.25 & 2.5 \\
\hline Shigella dysenteriae & 0.62 & 1.25 \\
\hline Salmonella infantis & 2.5 & 5 \\
\hline Salmonella enteritidis & $\mathrm{Nd}^{*}$ & $\mathrm{Nd}^{*}$ \\
\hline Salmonella typhimurium & 0.31 & 0.62 \\
\hline Staphylococcus aureus & 1.25 & 2.5 \\
\hline
\end{tabular}

*Not detected. 
Table 5

Panel of test organisms for in vitro antibacterial screening

\begin{tabular}{|l|l|}
\hline \multicolumn{1}{|c|}{ Species } & \multicolumn{1}{c|}{ Antibiotic resistance pattern } \\
\hline Staphylococcus aureus & AN, AZM, FOX, CP \\
\hline Escherichia coli & AZM, CPM, CRO, CAZ, CTX, AM \\
\hline Shigella flexneri & AMC, NA, CAZ, AM, TIC, CTX, CRO, TE, S, SXT, CF \\
\hline Shigella sonnei & AMC, AM, TOB, TIC, CTX, CRO, TE, S, SXT \\
\hline Shigella dysenteriae & AMC, AM, TIC, CTX, CRO, K, GM \\
\hline Salmonella infantis & AMC, NA, CAZ, AM, TIC, CTX, CRO, CT, PIP, D, TE, S, SXT, CF \\
\hline Salmonella enteritidis & AMC, NA, AM, PIP, D, TE, SXT \\
\hline Salmonella typhimurium & AMC, AM, PIP, TE, S, C \\
\hline
\end{tabular}

AN: Amikacin, AZM: Azithromycin, FOX: Cefoxitin, CPM: Cefpiramide, CP: Ciprofloxacin, CRO: Ceftriaxone, CAZ: Ceftazidime, CTX: Cefotaxime, AM: Ampicillin, AMC: Amoxycillin-clavulanic acid, NA: Nalidixic acid, TIC: Ticarcillin, TE: Tetracycline, S: Streptomycin, SXT: Trimethoprim-sulfamethoxazole, CF: Cephalothin, TOB: Tobramycin, K: Kanamycin, GM: Gentamycin, CT: Ceftizoxime, PIP: Piperacillin, D: Doxycyllin, C: Chloramphenicol

\section{DISCUSSION}

Recently, searching for new and effective antibacterial agents has become a very important and serious global concern, considering escalating levels of antibiotic resistance among pathogenic bacteria species which continuously challenges the scientific community $[8,9]$. Hence, many studies are directed to discover more organic and natural compounds for this solution [37]. One of the efforts in this research is focused on the use of essential oil extracted from plants, which has been applied for human diseases for a long time because of components having therapeutic value [2]. Essential oils contain diverse classes of bioactive compounds which are responsible, in turn, for various pharmacological properties [14, 21, 40]. A number of reports are available on the antifungal, antiviral, antibacterial, and anti-inflammatory properties of plant extracts, fractions and essential oils, thus therapeutic properties of medicinal plants are well recognized [5, 31].

In our study, a total of 36 compounds that exhibit $97.9 \%$ of the oil were identified in Ch. album subsp. striatum by GC-MS, like hydrocarbons and oxygenated and bicyclic mono-, di- and sesquiterpene hydrocarbons, and fatty acids. Usman et al. [36] reported that $\alpha$-pinene was the most abundant hydrocarbon monoterpene, but $\beta$-pinene $(6.2 \%)$ and limonene $(4.2 \%)$ were also found in higher amount in the oil of Ch. album [36]. The most abundant oxygenated monoterpene in the oil was pinane2 -ol (9.9\%), and $\alpha$-terpineol (6.2\%) and linalyl acetate $(2.0 \%)$ also occurred in detectable quantities in this earlier report. Our results about some chemical and bioactive of compounds of Ch. album subsp. striatum essential oil are in accordance with the previous study. The differences in chemical compositions and content could be attrib- 
uted to several factors such as the different methods of the extraction of the essential oil, stage of plant growth and lots of other factors [7, 20].

It is imperative that less expensive antibacterial agents should be developed to cure patients, regardless of financial status. So, medicinal plants can be the best option. As we mentioned before, some medicinal plants have been known for their antibacterial properties, but their efficacies against MDR bacteria have not been well-documented in the medicinal literature. Agar well, disc diffusion and also microdilution method were used in the present study as antibacterial tests because it is a quantitative reference method routinely used in clinical laboratories. Compared with agar-based methods, broth microdilution can decrease much labor and time [38]. In this study, high concentration of essential oil showed antibacterial activity against the tested MDR bacteria by all applied methods. The low value of the concentration was not as effective as high-value concentration and they did not show any antibacterial activity. There were exceptions, for example, against $S$. aureus in disc diffusion method, small concentration of essential oil was effective. Generally, it has been surmised that the antibacterial activities of plant extracts and essential oils are due to the presence of various bioactive compounds [12]. Ch. album subsp. striatum showed significant antagonist activities against MDR Gram-positive and Gram-negative bacteria. Varying agar well and disc diffusion, MIC and MBC values could be attributed to the reinforced defense mechanism acquired by MDR bacteria. The data presented in this study describe the broad-spectrum antimicrobial activity of Ch. album subsp. striatum essential oil as a novel and cost-effective antibacterial agent against MDR bacteria. In addition, it also provide a basis for reviving investigation on the biopharmaceutical diversity of essential oils. Additional and complementary studies are required concerning phytochemical screening, physiological analysis, isolation, purification and quantification of bioactive components of the plant for its in vivo assessment.

\section{ACKNOWLEDGEMENTS}

The authors thank for the help of all colleagues of Faculty Member of Production and Research Complex, Pasteur Institute of Iran.

\section{REFERENCES}

1. Abew, B., Sahile, S., Moges, F. (2014) In vitro antibacterial activity of leaf extracts of Zehneria scabra and Ricinus communis against Escherichia coli and methicillin resistance Staphylococcus aureus. Asian Pac. J. Trop. Biome. 4, 816-820.

2. Adegoke, A. A., Adebayo-Tayo, B. C. (2009) Antibacterial activity and phytochemical analysis of leaf extracts of Lasienthera africanum. Afr. J. Biotechnol. 8, 77-80.

3. Akthar, M. S., Degaga, B., Azam, T. (2014) Antimicrobial activity of essential oils extracted from medicinal plants against the pathogenic microorganisms: a review. IBSPR 2, 1-7.

4. Bassolé, I. H. N., Juliani, H. R. (2012) Essential oils in combination and their antimicrobial properties. Molecules 17, 3989-4006.

5. Behera, S. K., Misra, M. K. (2005) Indigenous phytotherapy for genito-urinary diseases used by the Kandha tribe of Orissa, India. J. Ethnopharmacol. 102, 319-325. 
6. Bhargava, A., Rana, T., Shukla, S., Ohri, D. (2005) Seed protein electrophoresis of some cultivated and wild species of Chenopodium. Biologia Plantarum 49, 505-511.

7. Burt, S. A., Vlielander, R., Haagsman, H. P., Veldhuizen, E. J. (2005) Increase in activity of essential oil components carvacrol and thymol against Escherichia coli O157: H7 by addition of food stabilizers. J. Food Protection 68, 919-926.

8. Chi-Cheng, L., Lee, K., Xiao, Y., Ahmad, N., Veeraraghavan, B., Thamlikitkul, V. (2014) High burden of antimicrobial drug resistance in Asia. J. Glob. Antimicrob. Resist. 2, 318-321.

9. Dinzedi, M., Okou, O., Akakpo-Akue, M., Guessennd, K., Touré, D., Nguessan, J. (2015) AntiStaphylococcus aureus activity of the aqueous extract and hexanic fraction of Thonningia sanguinea (Cote ivoire). Int. J. Pharmacognosy Phytochem. Res. 7, 301-306.

10. Djeussi, D. E., Noumedem, J. A., Seukep, J. A., Fankam, A. G., Voukeng, I. K., Tankeo, S. B., Nkuete, A. H. L., Kuete, V. (2013) Antibacterial activities of selected edible plants extracts against multidrugresistant Gram-negative bacteria. BMC Complement. Altern. Med. 13, 164.

11. Esfahan, E. Z., Assareh, M. H., Jafari, M., Jafari, A. A., Javadi, S. A., Karimi, G. (2010) Phenological effects on forage quality of two halophyte species Atriplex leucoclada and Suaeda vermiculata in four saline rangelands of Iran. J. Food Agric. Environ. 8, 999-1003.

12. Farzaneh, V., Carvalho, I. S. (2015) A review of the health benefit potentials of herbal plant infusions and their mechanism of actions. Ind. Crops. Prod. 65, 247-258.

13. Gawlik-Dziki, U., Świeca, M., Sułkowski, M., Dziki, D., Baraniak, B., Czyż, J. (2013) Antioxidant and anticancer activities of Chenopodium quinoa leaves extracts-in vitro study. Food. Chem. Toxicol. $57,154-160$

14. Haniyeh, K., Seyyednejad, S. M., Motamedi, H. (2010) Preliminary study on the antibacterial activity of some medicinal plants. Asian Pac. J. Trop. Med. 180-184.

15. Hakakian, A., Radjabian, T., Hassanpour Ezzati, M., Zarrei, M., Davari, A. (2017) Evaluation of analgesic and anti-inflammatory activities of Drosera spatulata. Int. J. Pharma. Sci. Res. 8, 10001006.

16. Hassanshahian, M., Tebyanian, H., Cappello, S. S. (2012) Isolation and characterization of two crude oil-degrading yeast strains, Yarrowia lipolytica PG-20 and PG-32, from the Persian Gulf. Mar. Pollut. Bull. 64, 1386-1391.

17. Hassanshahian, M., Ahmadinejad, M., Tebyanian, H., Kariminik, A. (2013) Isolation and characterization of alkane degrading bacteria from petroleum reservoir waste water in Iran (Kerman and Tehran provenances). Mar. Pollut. Bull. 73, 300-305.

18. Kang, C. G., Hah, D. S., Kim, C. H., Kim, Y. H., Kim, E., Kim, J. S. (2011) Evaluation of antimicrobial activity of the methanol extracts from 8 traditional medicinal plants. Toxicol. Res. 27, 31-36.

19. Khomarlou, N., Aberoomand-Azar, P., Lashgari, A. P., Hakakian, A., Ranjbar, R., Ayatollahi, S A. (2017) Evaluation of antibacterial activity against multidrug-resistance (MDR) bacteria and antioxidant effects of the ethanolic extract and fractions of Chenopodium album subsp. striatum. Int J. Pharma. Sci. Res. 8, 3696-3708.

20. Lv, F., Liang, H., Yuan, Q., Li, C. (2011) In vitro antimicrobial effects and mechanism of action of selected plant essential oil combinations against four food-related microorganisms. Food Res. Int. 44, 3057-3064.

21. Marjorie, M. (1999) Plant products as antimicrobial agents. Clin. Microbiol. Rev. 12, 564-582.

22. Murashige, T., Skoog, F. (1962) A revised medium for rapid growth and bio assays with tobacco tissue cultures. Physiologia plantarum 15, 473-497.

23. Nejma, A. B., Nguir, A., Jannet, H. B., Daïch, A., Othman, M., Lawson, A. M. (2015) New septanoside and 20-hydroxyecdysone septanoside derivative from Atriplex portulacoides roots with preliminary biological activities. Bioorganic Med. Chem. Lett. 25, 1665-1670.

24. Nowak, R., Szewczyk, K., Gawlik-Dziki, U., Rzymowska, J., Komsta, L. (2016) Antioxidative and cytotoxic potential of some Chenopodium L. species growing in Poland. Saudi. J. Biol. Sci. 23, 15-23.

25. Oluduro, A. O. (2012) Evaluation of antimicrobial properties and nutritional potentials of Moringa oleifera Lam. leaf in South-Western Nigeria. Malays. J. Microbiol. 8, 59-67. 
26. P. Srinivas, S. R. R. (2012) Screening for antibacterial principle and activity of Aerva javanica (Burm. f) Juss. ex Schult. Asian Pac. J. Trop. Biomed. 2 (Suppl. 2) 838-845.

27. Pelz, K., Wiedmann, Al Ahmad, M., Bogdan, C., Otten, J. E. (2008) Analysis of the antimicrobial activity of local anaesthetics used for dental analgesia. J. Med. Microbiol. 57, 88-94.

28. Pérez, C., Anesini, C. (1994) Antibacterial activity of alimentary plants against Staphylococcus aureus growth. Am. J. Chin. Med. 22, 169-174.

29. Poppe, C., Martin, L., Gyles, C., Reid-Smith, R., Boerlin, P., McEwen, S., Prescott, J. F., Forward, K. R. (2005) Acquisition of resistance to extended-spectrum cephalosporins by Salmonella enterica subsp. enterica serovar Newport and Escherichia coli in the turkey poult intestinal tract. Appl. Environ. Microbiol. 71, 1184-1192.

30. Repo-Carrasco-Valencia, R., Hellström, J. K., Pihlava, J. M., Mattila, P. H. (2010) Flavonoids and other phenolic compounds in Andean indigenous grains: Quinoa (Chenopodium quinoa), kañiwa (Chenopodium pallidicaule) and kiwicha (Amaranthus caudatus). Food Chem. 120, 128-133.

31. Samy, R. P., Ignacimuthu, S. (2000) Antibacterial activity of some folklore medicinal plants used by tribals in Western Ghats in India. J. Ethnopharmacol. 69, 63-71.

32. Soković, M., Glamočlija, J., Marin, P. D., Brkić, D., Van Griensven, L. J. (2010) Antibacterial effects of the essential oils of commonly consumed medicinal herbs using an in vitro model. Molecules 15, $7532-7546$

33. Tawfik, W. A., Abdel-Mohsen, M. M., Radwan, H. M., Habib, A. A., Yeramian, M. A. (2011) Phytochemical and biological investigations of Atriplix semibacatar Br. growing in Egypt. Afr. $J$. Tradit. Complement. Altern. Med. 8, 435-443.

34. Tebyanian, H., Hassanshahian, M., Kariminik, A. (2013) Hexadecane-degradation by Teskumurella and Stenotrophomonas strains isolated from hydrocarbon contaminated soils. Jundishapur J. Microbiol. 6, 1-7.

35. Tebyanian, H., Mirhosseiny, S. H., Kheirkhah, B., Hassanshahian, M. (2014) Isolation and identification of mycoplasma synoviae from suspected ostriches by polymerase chain reaction, in Kerman Province, Iran. Jundishapur. J. Microbiol. 7, 1-5.

36. Usman, L. A., Hamid, A. A., Muhammad, N. O., Olawore, N. O., Edewor, T. I., Saliu, B. K. (2010) Chemical constituents and anti-inflammatory activity of leaf essential oil of Nigerian grown Chenopodium album. EXCLI J 9, 181-186.

37. Villasenor, I. M., Lamadrid, M. R. A. (2006) Comparative anti-hyperglycemic potentials of medicinal plants. J. Ethnopharmacol. 104, 129-131.

38. Wayne, P. A. (2006) Clinical and laboratory standards institute: Performance standards for antimicrobial disc susceptibility tests. Approved standard M2-A9, Clinical and Laboratory Standards Institute.

39. Wikaningtyas, P., Sukandar, E. Y. (2016) The antibacterial activity of selected plants towards resistant bacteria isolated from clinical specimens. Asian Pac. J. Trop. Biomed. 6, 16-19.

40. Yazdi, H., Karami, A., Babavalian, H., Mirhosseini, S. A., Tebyanian, H. (2016) The effects of some physicochemical stresses on Escherichia coli $\mathrm{O} 157$ : $\mathrm{H} 7$ as clinical pathogenic bacteria. Int. J. Agri. Biol. 18, 1237-1241.

41. Zare, K. H., Nazemyeh, H., Lotfipour, F., Farabi, S., Ghiamirad, M., Barzegari, A. (2014) Antibacterial activity and total phenolic content of the Onopordon acanthium L. seeds. Pharma. Sci. 20, 6-11.

42. Zarparvar, P., Amoozegar, M. A., Babavalian, H., Reza, F. M., Tebyanian, H., Shakeri, F. (2016) Isolation and identification of culturable halophilic bacteria with producing hydrolytic enzyme from Incheh Broun hypersaline wetland in Iran. Cell. Mol. Biol. (Noisy-le-Grand, France) 62, 31-36. 